\title{
'XYZ' Application as a Tool for Teaching and Learning in Institutions of Higher Learning: An Exploratory Study
}

(Aplikasi 'XYZ'Sebagai Alat untuk Pengajaran dan Pembelajaran di Institusi Pengajian Tinggi: Satu Kajian Tinjauan)

\author{
Saroja Dhanapal \\ Nadhratul Wardah Salman \\ (Faculty of Law, University of Malaya) \\ Gopinathan K. Raman Kutty \\ (Faculty of Education, University of Malaya) \\ Khalid M.S. Ansari \\ Sardar Ali Shah \\ (Faculty of Law, University of Malaya)
}

\begin{abstract}
Teaching and learning in institutions of higher learning has undergone transformation as a result of rapid development in the field of communication and technologies. The emergence of social networking sites has paved the way for the enhancement of teaching and learning approaches. The focus of this study is on 'XYZ' application (the actual name is not disclosed due to confidentiality) that was recently launched in Malaysia. Using a mixed research method, the study investigated the perceptions of undergraduate students in a public university to identify the viability of this application in comparison with other applications and to analyze its effectiveness as a tool for teaching and learning. The findings indicate the application has good features that enhance the effectiveness of the teaching and learning process. However, there is concern about the limited compatibility of this application. The paper ends with recommendations on how the application can be improved.
\end{abstract}

Keywords: Teaching and learning; social networking sites; communication; M-learning; meeting room

ABSTRAK

Pengajaran dan pembelajaran di institusi pengajian tinggi telah mengalami transformasi hasil daripada perkembangan pesat dalam bidang komunikasi dan teknologi. Kemunculan laman rangkaian sosial telah membuka ruang untuk mempertingkatkan pendekatan kepada pengajaran dan pembelajaran. Kajian ini memberi tumpuan kepada aplikasi 'XYZ' (nama sebenar tidak didedahkan di atas faktor kerahsiaan) yang baru dilancarkan di Malaysia. Dengan menggunakan metodologi penyelidikan bercampur, kajian ini menyiasat persepsi para pelajar ijazah dasar di sebuah universiti awam bagi mengenal pasti kebolehjayaan aplikasi baru ini berbanding dengan aplikasi sedia ada yang lain dan menganalisis keberkesanannya sebagai alat pengajaran dan pembelajaran. Hasil dapatan menunjukkan bahawa aplikasi ini mempunyai ciri-ciri baik yang boleh meningkatkan keberkesanan proses pengajaran dan pembelajaran. Walau bagaimanapun, terdapat kebimbangan terhadap limitasi dalam aspek keserasian aplikasi. Artikel ini diakhiri dengan cadangan bagaimana aplikasi ini boleh diperbaiki.

Kata kunci: Pengajaran dan pembelajaran; laman rangkaian social; komunikasi; pembelajaran mudah alih; bilik mesyuarat

\section{INTRODUCTION}

The advancement in the field of science and technology has brought numerous changes in the field of education. According to Mayur and Ojode (2017), there is now a trend where "modes of instruction delivery continue to evolve at an accelerating rate due to incessant advances in technology." They cited the example of "smart classrooms that are equipped with state-of-the-art multi-media technology which gives instructors a wide range of options to suit nearly every instruction style." Development of communication applications such as WhatsApp, Line, Facebook and WeChat are increasingly being used to enhance the effectiveness of teaching and learning in institutions of higher learning. According to Wang and Shen (2012), the demands for an increasingly knowledgebased society and advances in mobile technology have combined to spur the growth of mobile learning which has introduced new learning media and tools that has changed learning concepts and have provided new modes of interactive learning. As a result, mobile learning (M-learning) has gained importance and popularity amidst students and educators not only for teaching and learning activities but also as a tool for assessment. In essence, the term M-learning is used to depict a form of learning where knowledge is disseminated to students through handheld 
or portable devices. It is similar to E-learning as both Elearning and M-learning utilize digital communication in delivering education. The main difference is M-learning is limited to the use of mobile phones while E-learning adopts all web-enabled devices such as PDAs, notebooks and laptops (Girgin, Kurt \& Odbasi 2011). Today, the use of M-learning has made it possible for teaching and learning to take place anywhere at any time. However, successful use of M-learning still depends on students' attitude towards these technologies (Iqbal \& Qureshi 2012)

According to Yalcinalp and Gulbahar (2010), the use of communication applications in the teaching and learning process has a lot of benefits. These include motivating "learners to learn by anticipating needs; make collaborative learning efficient and effective as well as building a relationship that stimulates learner-to-learner for consistent and progressive learning." Although past researches (Rau, Gao \& Wu 2008; Cheon, Crooks \& Song 2012) have indicated that M-learning has impacted teaching and learning in a positive manner, there is still a dearth of literature to determine the comparative advantages and disadvantages as well as the challenges that arise from the use of the different applications available today. 'XYZ' (the name of this application is not disclosed due to confidentiality issue for the protection of the company's viability) is a new mobile application which was introduced in 2018. It is a messaging application that has a number of features where some are common with other applications while others are new ones which focus on entertainment and security. It is fast, simple, secure and free. It seamlessly syncs normal messages and secret messages into one application. Users can send an unlimited number of messages, photos and voice messages like in any other applications. Its group feature allows users to send broadcasts to up to 100 contacts at a time. It also allows secret messages to be sent which are not stored in the phone when the conversation has ended.

Since research has not been done on this application, the current research aims to explore three main objectives: firstly, to analyze 'XYZ' as a communication application in comparison with other available communication applications; secondly, to analyze the perceptions of students on the use of ' $\mathrm{XYZ}$ ' as a tool for teaching and learning and thirdly, to identify the benefits and challenges of 'XYZ' as a tool for teaching and learning. The paper ends with suggestions on what the designers of ' $\mathrm{XYZ}$ ' can do to ensure the competitiveness and sustainability of this application with other communication applications available.

The current research is significant as it validates the framework proposed by Sharples, Taylor and Vavoula (2005) where it is asserted that learning occurs in a sociocultural context which comprises of learners, educators and technology. Further, this research is important as it would contribute to the teaching and learning processes in the $21^{\text {st }}$ century where technological instruments including mobile phones are adopted to enhance the learning that takes place. The findings from the survey will add to the existing knowledge on the benefits and challenges faced by students in the use of mobile technology in the learning process and assist educators to understand students' perceptions and use the technology more effectively. Further, the comparative analysis will also enable educators to select the mobile application that best suits their course learning outcomes.

\section{LITERATURE REVIEW}

Literature review for this paper covers social media, Mlearning as well as teaching and learning. Social media is a growing phenomenon with varied definitions. According to Mangold and Faulds (2009), social media encompasses a wide range of online word-of-mouth forums including blogs, company sponsored discussion boards and chat rooms, consumer-to-consumer e-mail, consumer product or service ratings websites and forums, internet discussion boards and forums, moblogs (sites containing digital audio, images, movies or photographs) and social networking websites, to name a few. According to Nicholson (2011), "M-learning encompasses any activity where humans share stories and influence others." He went on to state that it can be considered as a form of social networking. In the $21^{\text {st }}$ century, social media has become a popular forum for discussing topics of interest, meeting or renewing acquaintances with others on a virtual platform.

In short, social media is a form of electronic communication which allows interaction among people who are "freely sharing, exchanging and discussing information, ideas, personal messages and other content about each other and their lives" (Cox \& Rethman 2011). This is done by using multimedia devices which combine words, pictures, videos and audio, through the use of internet connected online platform. According to Darwish and Lakhtaria (2011), social media that emerged with the rise of Web 2.0 technologies are "characterized by several significant features such as user generated content, online identity creation and relational networking." This is supported by Smith (2010), who claims that "social media sites are virtual platforms for interactivity and information exchange ... where issues are debated and defined ..., users collaborate in content creation ... and are proactive in searching information."

Since its inception, social media has changed people's lives. Currently there are many platforms such as Facebook, Twitter, MySpace and YouTube that allow people from all over the world to connect including employees, friends and families. A report by Nielsen (2010), a global measurement and data analytics company states that "social media accounts for nearly one-quarter of all internet activity, and statistics has shown that LinkedIn has over 80 million professionals in over 200 countries." It can be concluded that social media has changed communication between people around the globe. 
The numerous social network sites (SNSs) available today enable connection between people beyond geographical boundaries. Edosomwan et al. (2011) claim that "the concept of social networking has evolved, much like other innovations and is becoming increasingly sophisticated with advancements in technology". According to Boyd and Ellison (2007: 1), "an online social network site is a web-based service that allows individuals to construct a semi-profile within a bounded system, articulate to a list of other users with whom they share connection with as well as view and go through their list of connections and those made by others within the system although the nature and nomenclature of these connections has variation. In sum, SNS (social networking service) is a communication tool, a platform designed to enable discussions and interactions between people. It allows users to explore new opportunities and experiences. As a result, today people interact through multimedia devices which do not require face to face discussion.

There are numerous definitions to the term ' $\mathrm{M}$ learning.' According to Mcconatha, Praul and Lynch (2008), M-learning is learning that employs through the use of small computing mobile devices. Mirski and Abfalter (2004), on the other hand, defined M-learning as a specific emerging form of distance learning. Mlearning has also been equated to an approach to teaching and learning for future generations (Hahn 2008). With regards to impact, Al Emran and Shaalan (2014) stated that M-learning has changed the way students interact with each other as it facilitates knowledge sharing among students and educators. It must be noted that the study on M-learning emphasises that mobile technology is creating a useful and conducive learning environment (Gasmi 2014; Ngaleka \& Uys 2013). According to Kietzmann et al. (2011), social media employs mobile and web-based technologies to create highly interactive platforms through which individuals and communities share, co-create discuss and modify user-generated content. Social media that uses online platforms seems to promote collaboration as well as opportunities for sharing information in education (Junco, Helbergert \& Loken 2011) in order to facilitate learning (Kabilan, Ahmad \& Abidin 2010). This is supported by Lynch (2017) who claims that "digital technology has enhanced the future of learning and has enabled students and educators alike from all over the world to work together, spread knowledge and increase learning opportunities for everyone."

For students, SNSs allow them to express themselves and communicate without limitation. Thus, students are utilizing these social networks for various activities such as news feeds, personal updates, events and activities, notes, and messages. According to Mazer, Murphy and Simonds (2007), positive perceptions obtained from users of SNS show an easy learning climate among students has been established. Keenan and Shirii (2009) conducted a study to identify the impact of SNSs for encouraging sociability through the use of Facebook, Twitter and LinkedIn. Their findings concluded that amiability among students can lead to a positive effect with the adoption of these various sites. According to Churchill (2009), the use of weblogs or 'blogs' in education facilitate a conducive teaching and learning environment because these tools provide knowledge sharing.

Further, according to Roblyer et al. (2010), among the many benefits in the use of SNSs among students, enhancing communication is the most prevalent. However, a number of researchers have identified negative implications of SNSs. According to de Villiers (2010), "most SNSs users show positive behaviors, however, instead of finding academic information, they spend their time doing other irrelevant activities." He confirmed this through a survey where only 9 out of 200 students showed tendency to use SNSs for purely academic purpose. This is supported by Kuppuswamy and Narayan (2010) who pointed out that 'SNSs can easily divert the attention and focus of the students towards non-academic, unethical behaviors such as purposeless chatting, time wasting by surfing SNSs and eventually not completing their tasks.' Although WhatsApp and Facebook have been established as popular among students and faculty members as engaging tools which provide conducive learning environment by Alshahrani and Al-Shehri (2012) and a number of other researchers (Bouhnik \& Deshen 2014; Kabilan et al. 2010; Mahdi \& Elnaim 2012), there are negative perceptions on the implications of these SNSs on students' academic performance (Baran 2010). Table 1 shows the summary of the literature review related to the current research.

A number of researchers have carried out researches on the use of SNSs in classroom settings with the purpose of identifying their impact on the teaching and learning process (Lynch 2017; de Villiers 2010; Alshahrani \& Al-shehri 2010; Baran 2010; Kolan \& Dzandza 2018). Nicholson's (2011) research on the history of social networking asserted that it is not a new tool but became new as a result of its transformation as a digital and online tool which brought online conversation to the main stream. Junco et al. (2011) added by stating social networking platforms impact students' engagement. His research findings showed that students and faculty members were highly engaged in the learning process. Ngaleka and Uys (2013) emphasized that there is significant collaboration and learning between lecturers and students outside the classrooms when WhatsApp was used to facilitate a project which involved field work. Further, the findings of Bouhnik and Deshen's (2014) exploratory research indicated that using WhatsApp helped to cultivate a sense of belonging among students and teachers. In addition, Mahdi and El-Naim (2012) concluded that the use of computer-mediated communication has a positive impact in enhancing the users' language.

Sharples et al. (2005) qualitative research showed how mobile learning supports virtual communities that transcend barriers of age and culture. Further, other researchers such as Keenan and Shiri (2009) as well as Lynch (2017) have discussed the benefits of SNSs in 
TABLE 1. Past studies on the usage of IT, social networking sites and mobile phone in the process of teaching and learning

\begin{tabular}{cl}
\hline Authors & Focus \\
\hline Lynch (2017); de Villiers (2010); & Use of SNSs in classroom settings \\
Alshahrani \& Al-shehri (2010); & and its impact
\end{tabular}

Alshahrani \& Al-shehri (2010); and its impact

Baran (2010) and Kolan \&

Dzandza (2018)

Nicholson (2011)

Junco et al. (2011)

Ngaleka and Uys (2013)

Bouhnik and Deshen (2014)

Sharples, Taylor and Vavoula (2005)

Keenan and Shiri (2009)

Mcconatha et al. (2008)

Kuppuswamy and Narayan (2010)

Mayur and Ojode (2017)

Mirski and Abfalter (2004)

Smith (2010)
History of social networking

Impact of the use of Twitter - the microblogging and social networking platform on college students' engagement and grades.

Use of mobile phones as a platform to pursue collaborative research work

Explore the usage of WhatsApp in a classroom.

Investigate the impact of informal use of computer-mediated communication (CMC) on learner's interaction. Identify how context affects he use of technology. Explore sociability on the social web and details how different social websites encourage their users to interact.

Assess the possible methods, challenges and future potential of using M-learning in a college classroom.

Identify the positive and negative impact of social network sites on society.

Discuss social network web sites' implications for the curriculum Identify the possibility and potential for mobile learning services for tourism and leisure.

Explore social public relations through a qualitative analysis of user involvement on Twitter regarding relief efforts to support Haiti victims.
- Social networking service has enhanced the learning process with benefits such as enabling students and educators alike from all over the world to work together, spread knowledge, built relationships, enable distance learning and increase learning opportunities for everyone. - The use has raised some issues such as addiction which causes distractions.

- It is not a new tool but became new as a result of its transformation as a digital and online tool.

- Use of Twitter communications showed that students and faculty were both highly engaged in the learning process and it provided evidence that using Twitter did not only increase student engagement but also improved grades and thus, helped students reach desired college outcomes. - Findings indicated significant collaboration and learning taking place outside the classroom without the influence of the lecturer. However, students also spent time, discussing irrelevant things.

- Findings revealed that WhatsApp has educational and academic potentials as it enabled the ability to access information, content, support and personal aid on a regular basis with special significance for students who come from a non-nurturing environment.

- The use of informal CMC also increases the interaction between language learners, their teachers and their peers.

- Results indicated that the interactions between learning technology are complex and varied.

- Social websites promotes privacy and represents 'real world' networks in web environment.

- M-Learning devices are tremendously helpful in expanding the distance learning world.

- Social networking websites distract students from their studies but these websites are useful for education based on sound pedagogical principles and proper supervision by the teachers.

- Social media is a potential channel for instructional content delivery that can help enhance student learning. - There were significant differences among the students' attitudes towards M-learning with regard to their smartphone ownership, country and age.

- M-learning can be one of the promising pedagogical technologies to be employed in higher educational environments within the Arab Gulf countries.

- The analysis of Twitter posts indicate that they expand understanding and demonstrate social media users' fulfillment of public relations objectives. 
both virtual and real-life classrooms. Mcconatha et al. (2008) have asserted that mobile learning is relatively a new pedagogical tool which provides students with a higher level of knowledge compared to students who are given face to face instruction and this was proven in their research. It is important to note Kuppuswamy and Narayan's (2010) research which highlighted the negativity of SNSs in distracting students also claimed that through proper supervision by the teachers, SNSs are effective tools in the teaching and learning process. Ofcom (2017) highlighted the increasing trend in using SNSs especially among youngsters when they setup their profile while Mayur and Ojode (2017) confirmed the important role played by educationists in effectively utilising the SNSs in their classrooms to enhance students learning.

All these researches were carried out using a variety of methodologies comprising descriptive, qualitative and quantitative methods where data was collected via interviews and surveys. The findings of these researches indicate that the use of SNSs in the teaching and learning process does not only have a positive impact on the students but also raises some challenges. Further, these researches also recommended that educationists should take measures to address the challenges when using SNSs. Past literature review on social media has identified that there are still gaps in knowledge on the use of SNSs with many new communication applications being developed and continuously being used in institutions of higher learning through various approaches to meet the needs of the new technology savvy generation. As such, research on these new applications is highly crucial to ensure the effectiveness of their usage to promote and enhance teaching and learning in the $21^{\text {st }}$ century.

\section{METHODOLOGY}

This research adopted a mixed method research design combining qualitative and quantitative data collection methods. Data was collected through a few ways and the findings were then triangulated to ensure validity and reliability. In the qualitative research method, data was collected via document analysis and interviews. For document analysis, both primary and secondary sources were analyzed. The primary sources being 'XYZ"s website and the other communication applications' websites. The secondary sources comprise books, articles, online sources and reports which were also analyzed. Interviews were conducted among the undergraduate law students in a public university in Malaysia. The data for the quantitative study was obtained by way of a survey design using a 5 Likert scale which was administered among 263 students using a non-probability purposive method. The questionnaire was designed by the researchers and a pilot test was carried out among 30 students to identify flaws in the questionnaire which was rectified. Further, a computer science expert was asked to review the questionnaire for further improvement before it was administered. The researchers adopted this sampling method because the 'XYZ' application had not been officially launched. Thus, the designers of the application came to the selected university where they gave access to the students by registering them as users. These students were then asked to use the application for a duration of 3 months including participation in activities designed by the lecturer using the application. After the duration, these students took part in the survey and the collected data was then tabulated and analysed using SPSS Version 24. The fact that all the survey samples were undergraduate law students is just a matter of convenience as the study was carried out at the law faculty of a public university where two of the researchers are lecturers and two are PhD candidates. Thus, the field of study of the students has no significance to the research. A total of 30 students from the survey were selected randomly to be interviewed to obtain specific perceptions on the features of the Meeting Room and games available on the application. Two questions were posed to them and their responses were analysed using a thematic approach. The questions posed were as follows:

$\mathrm{Q}_{1}$ How did you find the use of Meeting Room as a teaching/learning tool?

$\mathrm{Q}_{2}$ How did you find the game given to your group? State all the interesting features as well as any challenges while playing game?

The interviews were carried out one week after the survey. The interviews were transcribed and analyzed using NVivo.

This study adopted the framework proposed by Sharples et al. (2005) which was adapted from Engeström's expansive activity model. This theoretical framework is indicated in Figure 1. The framework indicates that learning is a socio-cultural system where educators and technology are the controls, 'context' is the communities of actors (people and technology) and 'communication technology' adaption drives the use of technology in M-learning. According to Sharples et al. (2005), "the implementation to any educational technology should consist of three parts; the learner, the educator and the technology itself."

In this study, the three parts that Sharples et al. (2005) refer to in their framework comprised learners (undergraduate law students), educators (lecturer) and the technology ('XYZ'Application). The lecturer used 'XYZ' as a tool for e-learning where students were given activities to do during a specific lecture slot using the 'XYZ' Meeting Room. They were also asked to try out some games on the application to test the features after which the survey and interviews were carried out. Figure 2 summarises the whole research process.

\section{FINDINGS AND DISCUSSION}

The findings from the survey and interviews conducted among undergraduate law students in a public university 


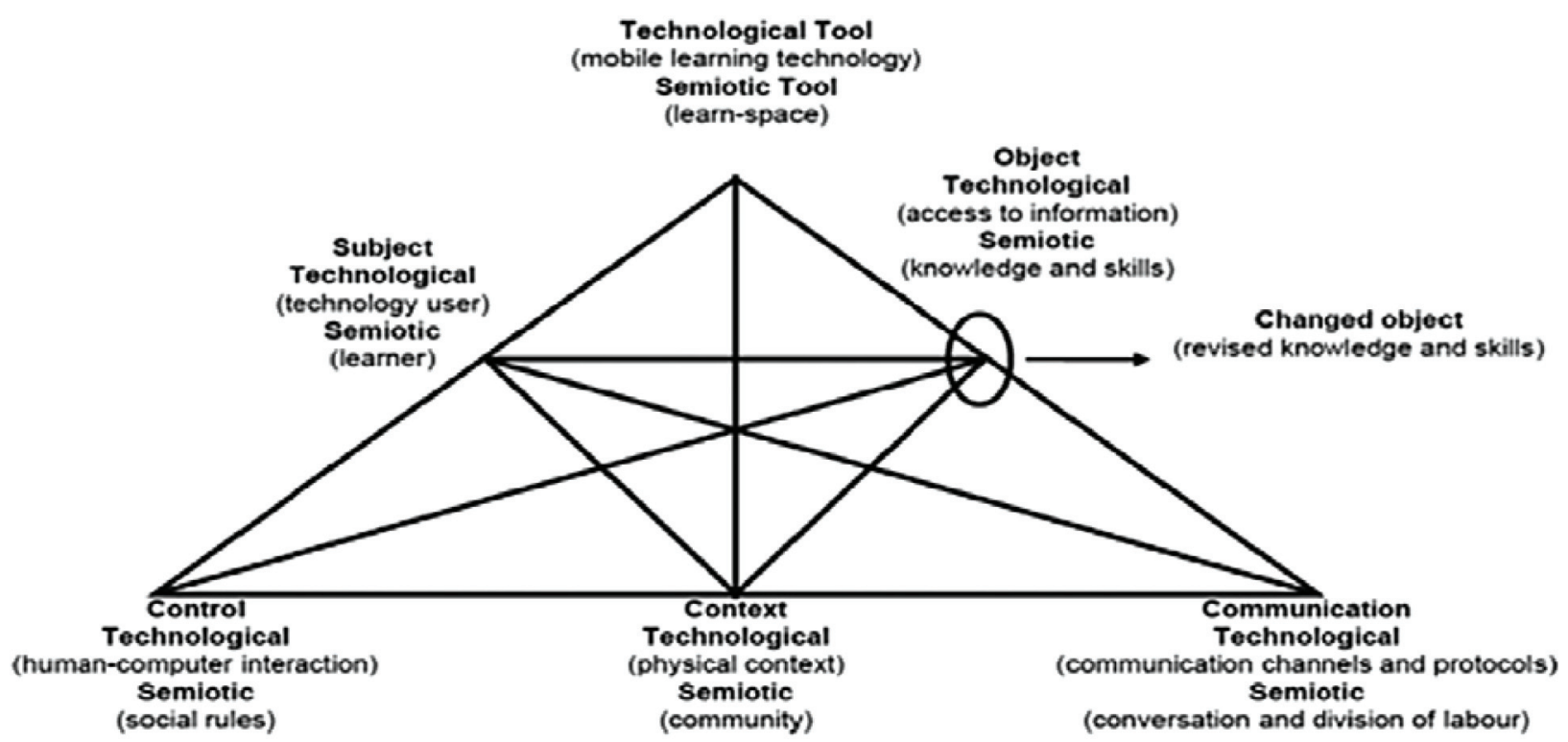

FIGURE 1. A task model for mobile learning (Sharples, Taylor \& Vavoula 2005)

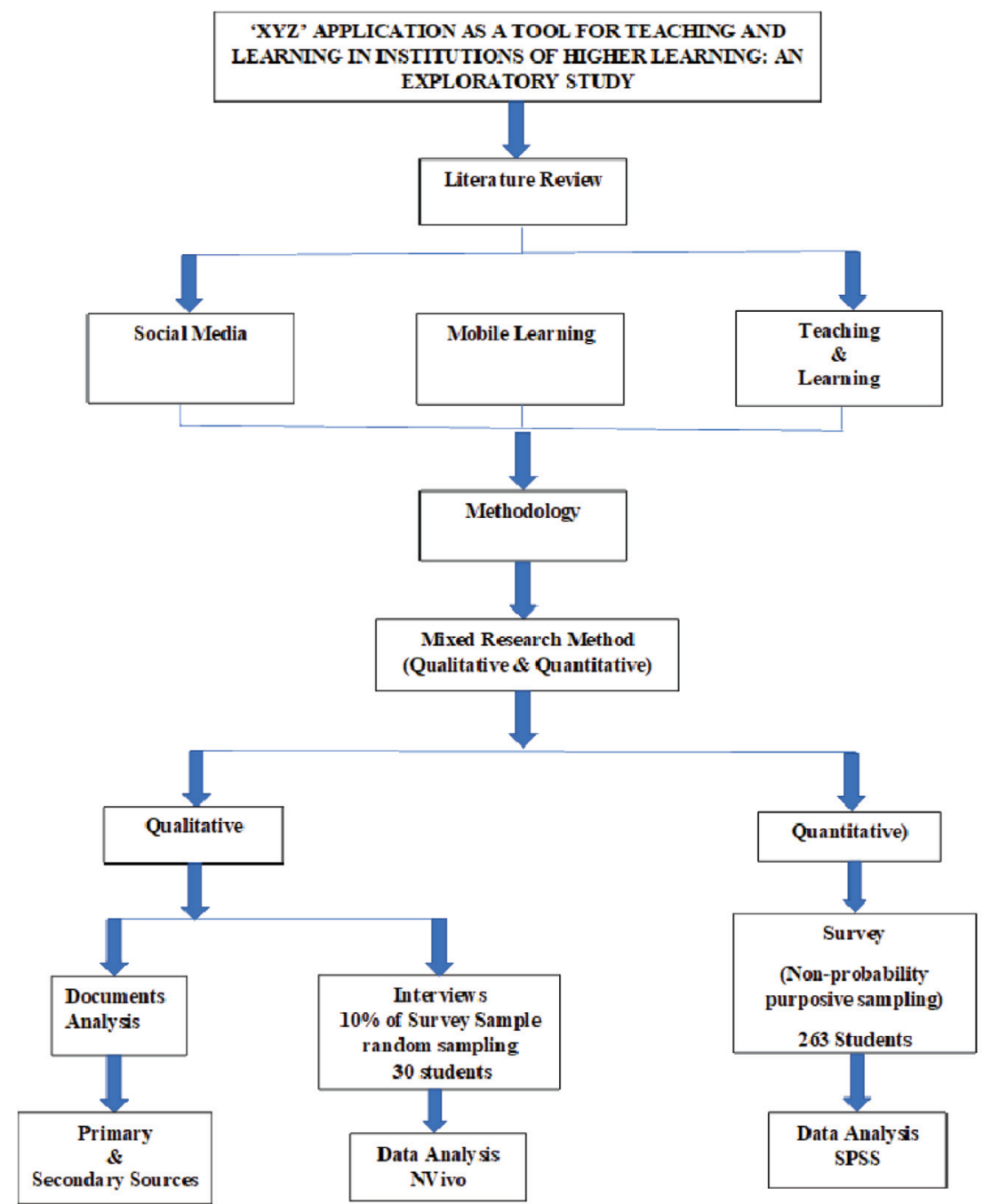

FIGURE 2. Research flowchart 
in Malaysia are discussed here. The survey questionnaire on the use of 'XYZ' as a teaching and learning tool consists of six parts; demographics, students' perceptions of research comparing 'XYZ' with five other communications applications, benefits of 'XYZ,' challenges in the usage of 'XYZ' application, skills developed in the use of 'XYZ', overall perceptions of 'XYZ' and finally suggestions for the improvement of 'XYZ.' For ease of understanding, tables and graphs are used to present and discuss the findings.

A total of 300 survey questionnaires were distributed but only 263 were returned. The data was tabulated in SPSS version 24 and different statistical analysis were carried out. Table 2 shows the demographics of the respondents. The demographics include details such as year of study, gender and race.

TABLE 2. Demographics

\begin{tabular}{lc}
\hline Items & $\mathrm{n}(\%)$ \\
\hline Year of Study & \\
Year 1 & $20(7.6)$ \\
Year 2 & $125(47.5)$ \\
Year 3 & $118(44.9)$ \\
Gender & \\
Male & $77(29.3)$ \\
Female & $186(70.7)$ \\
Race & \\
Malay & $104(39.5)$ \\
Chinese & $121(46.0)$ \\
Indian & $25(9.5)$ \\
Others & $13(4.9)$ \\
\hline
\end{tabular}

With reference to year of study, the majority was year 2 students (47.5\%), followed by year 3 (44.9) and year 1 at $7.6 \%$. The distribution of respondents between gender indicated an imbalance; $70.7 \%$ females and $29.3 \%$ males. This unequal percentage is not surprising as the report by Statista (2018) indicated the number of female students enrolled in public higher education institutions in Malaysia outnumbered male students. In 2016 , approximately 399,240 female students had enrolled in public higher education institutions in Malaysia compared to around 268,250 male students. The analysis of the respondents' race indicates the majority was Chinese (46\%) followed by Malays (39.5\%), Indian (9.5\%) and others $(4.9 \%)$. Table 3 shows the findings from Section $\mathrm{B}$ of the survey questionnaire which required students to give their perceptions of 'XYZ' in comparison with other communication applications that are available.

The findings in Table 3 clearly show that students have negative perception about the features in 'XYZ.' Out of 15 positive statements provided about 'XYZ,' only 3 had high percentage of agreement; ' $\mathrm{XYZ}$ ' is the newest application available in the market' $(53.6 \%)$, 'exposure to 'XYZ' is still at its infancy stage' $(87.8 \%)$ and ' $\mathrm{XYZ}$ ' is the only application which has White Board' (46\%). These results clearly indicate that ' $\mathrm{XYZ}$ ' is still not as efficient as other communication applications that have been in the market longer. Among the statements where there was a high percentage of disagreement about 'XYZ"s features are; "XYZ"s social feature is better than the one of WeChat and Line' (70.7\%), 'XYZ' is the only application which has Live Streaming' (68.1\%), “XYZ”s Revoke Message feature is better than WeChat and WhatsApp' (68.1\%), "XYZ' has the best message/voice call /video call features' $(67.7 \%)$ and "XYZ"s Beauty Face Video Call feature is better than Snapchat's (66.2\%). Other statements which were disagreed by the students about 'XYZ"s features as compared with various applications include 'read and burn' feature is better than Snapchat, 'Newsfeed' feature is better than WeChat and Line, game features are better than WeChat and Line, Stickers feature is better than WeChat and Snapchat, Wallet feature is better than WeChat and Line and overall 'XYZ' has more features than the other applications. Another interesting finding from the research shows that $45.6 \%$ of the respondents agreed that the features of 'XYZ' are better than other applications. This is in consensus with the claim of Selwyn (2009) that SNSs are personal and personalized spaces for online conversations and sharing of content based typically on the maintenance and sharing of 'profiles' where individual users can represent themselves to other users through the display of personal information, interests, photographs and social networks. A descriptive statistic was carried out in SPSS to identify the mean score and Standard Deviations of items. The results indicate that items reported with high mean score are 'exposure to ' $\mathrm{XYZ}$ ' is still at its infancy stage' (Mean $2.81 \pm \mathrm{SD} 0.540$ ); 'XYZ' is the newest application available in the market' (Mean 2.24 \pm SD 0.882) and 'XYZ' is the only application which has White Board' (Mean 2.18 \pm SD 0.841). The items with lower mean scores are; 'XYZ's Revoke Message feature is better than WeChat and WhatsApp' (Mean $1.46 \pm$ SD 0.724); 'XYZ's social feature is better than the one of WeChat and Line' (Mean $1.46 \pm \mathrm{SD} 0.765)$ and ' $\mathrm{XYZ}$ ' has the best message/voice call /video call features' (Mean $1.48 \pm$ SD 0.756). Table 4 shows the findings on the benefits of ' $\mathrm{XYZ}$ ' as a tool for teaching and learning.

An analysis of the data tabulated in Table 4, clearly portrays that students did find 'XYZ' beneficial as a tool for teaching and learning. However, the percentages of agreement are not very high and ranges from $42.6 \%$ to $55.9 \%$. This shows that students do not perceive ' $\mathrm{XYZ}$ ' to be better than other applications. Among the benefits the students perceived include; 'XYZ' application offer opportunities for communication and team-working' (55.9\%), 'XYZ' application facilitates communication between students and their instructors' (55.1\%), 'The privacy of the Meeting Room is maintained as the status of who is typing the message is not shown unlike WhatsApp' (53.6\%), 'XYZ"s Meeting Room is accessible almost from anywhere and at any time which is convenient' (46.4\%), 'XYZ' application can be an easy way to get feedback and notification from my classmates and lecturers' (45.2\%), 'XYZ' application can bring many opportunities 
TABLE 3. 'XYZ' in comparison with other communication applications

\begin{tabular}{|c|c|c|c|c|}
\hline Items & $\begin{array}{l}\text { Disagree } \\
\mathrm{n}(\%)\end{array}$ & $\begin{array}{l}\text { Neutral } \\
\mathrm{n}(\%)\end{array}$ & $\begin{array}{l}\text { Agree } \\
\mathrm{n}(\%)\end{array}$ & Mean \pm SD \\
\hline ' $\mathrm{XYZ}$ ' is the newest app available in the market. & $78(29.7)$ & $44(16.7)$ & $141(53.6)$ & $2.24 \pm 0.882$ \\
\hline Exposure to 'XYZ' is still at its infancy stage. & $18(6.8)$ & $14(5.3)$ & $231(87.8)$ & $2.81 \pm 0.540$ \\
\hline 'XYZ' has the best message/voice call /video call features. & $178(67.7)$ & $43(16.3)$ & $42(16)$ & $1.48 \pm 0.756$ \\
\hline 'XYZ' is the only application which has White Board. & $73(27.8)$ & $69(26.2)$ & $121(46)$ & $2.18 \pm 0.841$ \\
\hline 'XYZ' is the only application which has Live Streaming. & $179(68.1)$ & $37(14.1)$ & $47(17.9)$ & $1.50 \pm 0.781$ \\
\hline 'XYZ"s social feature is better than the one of WeChat and Line. & $186(70.7)$ & $33(12.5)$ & $44(16.7)$ & $1.46 \pm 0.765$ \\
\hline 'XYZ' is the only application which has Secret Chat. & $146(55.5)$ & $30(11.4)$ & $87(33.1)$ & $1.78 \pm 0.916$ \\
\hline 'XYZ's Read and Burn feature is better than Snapchat. & $166(63.1)$ & $54(20.5)$ & $43(16.3)$ & $1.53 \pm 0.760$ \\
\hline 'XYZ's Revoke Message feature is better than WeChat and WhatsApp. & $179(68.1)$ & $48(18.3)$ & $36(13.7)$ & $1.46 \pm 0.724$ \\
\hline 'XYZ's Beauty Face Video Call feature is better than Snapchat. & $174(66.2)$ & $48(18.3)$ & $41(15.6)$ & $1.49 \pm 0.751$ \\
\hline 'XYZ's News Feed feature is better than WeChat and Line. & $169(64.3)$ & $49(18.6)$ & $45(17.1)$ & $1.53 \pm 0.770$ \\
\hline 'XYZ's Games feature is better than WeChat and Line. & $139(52.9)$ & $39(14.8)$ & $85(32.3)$ & $1.79 \pm 0.901$ \\
\hline 'XYZ's Stickers feature is better than WeChat, Snapchat, Line and Viber. & $158(60.1)$ & $34(12.9)$ & $71(27.0)$ & $1.67 \pm 0.874$ \\
\hline 'XYZ's Wallet feature is better than WeChat and Line. & $139(52.9)$ & $75(28.5)$ & $49(18.6)$ & $1.66 \pm 0.775$ \\
\hline $\begin{array}{l}\text { 'XYZ' has more features compared to the other communication } \\
\text { applications. }\end{array}$ & $103(39.2)$ & $40(15.2)$ & $120(45.6)$ & $2.06 \pm 0.920$ \\
\hline
\end{tabular}

SD stands for Standard Deviation

TABLE 4. Benefits of 'XYZ' as a tool for teaching and learning

\begin{tabular}{|c|c|c|c|c|}
\hline Items & $\begin{array}{l}\text { Disagree } \\
\mathrm{n}(\%)\end{array}$ & $\begin{array}{l}\text { Neutral } \\
\mathrm{n}(\%)\end{array}$ & $\begin{array}{l}\text { Agree } \\
\mathrm{n}(\%)\end{array}$ & Mean $\pm \mathrm{SD}$ \\
\hline 'XYZ' application is a useful tool for my study. & $142(31.2)$ & $36(13.7)$ & $85(32.3)$ & $1.78 \pm 0.905$ \\
\hline $\begin{array}{l}\text { 'XYZ' application can offer opportunities for communication and } \\
\text { team-working. }\end{array}$ & $80(30.4)$ & $36(13.7)$ & $147(55.9)$ & $2.25 \pm 0.895$ \\
\hline 'XYZ' application can help me in finding resources related to my study. & $172(65.4)$ & $42(16.0)$ & $49(18.6)$ & $1.53 \pm 0.790$ \\
\hline 'XYZ' application can bring many opportunities to the learning process. & $106(40.3)$ & $43(16.3)$ & $114(43.3)$ & $2.03 \pm 0.916$ \\
\hline $\begin{array}{l}\text { 'XYZ' application can help me to access course-materials anytime } \\
\text { anywhere. }\end{array}$ & $136(51.7)$ & $43(16.3)$ & $84(31.9)$ & $1.80 \pm 0.895$ \\
\hline $\begin{array}{l}\text { 'XYZ' application can be an easy way to get feedback and notification } \\
\text { from my classmates and lecturers. }\end{array}$ & $106(40.3)$ & $38(14.4)$ & $119(45.2)$ & $2.05 \pm 0.925$ \\
\hline $\begin{array}{l}\text { 'XYZ' application can help me to exchange course-materials with } \\
\text { my friends. }\end{array}$ & $107(40.7)$ & $44(16.7)$ & $112(42.6)$ & $2.02 \pm 0.914$ \\
\hline 'XYZ' application can help me to manage my study. & $167(63.5)$ & $40(15.2)$ & $56(21.3)$ & $1.58 \pm 0.820$ \\
\hline $\begin{array}{l}\text { 'XYZ' application facilitates communication between students and } \\
\text { their instructors. }\end{array}$ & $80(22.1)$ & $38(14.4)$ & $145(55.1)$ & $2.25 \pm 0.893$ \\
\hline 'XYZ' application can help me to develop my learning skills. & $137(52.1)$ & $40(15.2)$ & $86(32.7)$ & $1.81 \pm 0.902$ \\
\hline $\begin{array}{l}\text { The use of 'XYZ's Meeting Room is convenient for large groups } \\
\text { of people. }\end{array}$ & $111(42.2)$ & $38(14.4)$ & 114 (43.3) & $2.01 \pm 0.927$ \\
\hline $\begin{array}{l}\text { 'XYZ”'s Meeting Room is very interactive with amusing animation } \\
\text { features. }\end{array}$ & $101(38.4)$ & $82(31.2)$ & $89(30.4)$ & $1.92 \pm 0.827$ \\
\hline $\begin{array}{l}\text { 'XYZ's Meeting Room is accessible almost from anywhere and at any } \\
\text { time which is convenient. }\end{array}$ & $102(38.8)$ & $39(14.8)$ & $122(46.4)$ & $2.08 \pm 0.921$ \\
\hline $\begin{array}{l}\text { 'XYZ' can also be used by students who are physically challenged } \\
\text { (such as students who are blind). }\end{array}$ & $77(29.3)$ & $136(51.7)$ & $50(19.0)$ & $1.90 \pm 0.689$ \\
\hline $\begin{array}{l}\text { The privacy of the Meeting Room is maintained as the status of who } \\
\text { is typing the message is not shown unlike WhatsApp }\end{array}$ & $74(28.1)$ & $48(18.3)$ & $141(53.6)$ & $2.25 \pm 0.869$ \\
\hline
\end{tabular}


to the learning process' (43.3\%), 'The use of 'XYZ”'s Meeting Room is convenient for large groups of people' (43.3\%) and ' $\mathrm{XYZ}$ ' application can help me to exchange course-materials with my friends' $(42.6 \%)$. The findings that indicate that ' $\mathrm{XYZ}$ ' is effective for communication replicates the finding of Mangold and Faulds (2009) who asserted that the emergence of internet-based social media has enabled one person to communicate with large groups of people. Further, the students' responses that it is easy to get feedback is in accord with Mason's (2006) assertion that social networking applications share many of the desirable qualities of good 'official' education technologies - permitting peer feedback and matching the social contexts of learning such as the school, university or local community. The positive responses articulated by the respondents are also aligned with the findings of Greenhow (2011) who reported that the benefits in the use of SNSs can be divided into four overlapping categories which are greater access to information, emotional support, peer feedback, including help with school-related tasks and reinforcement of identity.

The findings revealed that the students also disagreed with a number of statements relating to the benefits of ' $\mathrm{XYZ}$ ' such as 'XYZ' application can help me in finding resources related to my study' (65.4\%), 'XYZ' application can help me to manage my study' (63.5\%), 'XYZ' application can help me to develop my learning skills' (52.1\%) and 'XYZ' application can help me to access course-materials anytime anywhere' (51.7\%). The descriptive results show that the items with high mean score are: 'XYZ' application can offer opportunities for communication and team-working' (Mean 2.25 \pm SD 0.895); 'XYZ' application facilitates the communication between students and their instructors' (Mean 2.25 \pm SD 0.893) and 'The privacy of the Meeting Room is maintained as the status of who is typing the message is not shown unlike WhatsApp' (Mean 2.25 \pm SD 0.869). The items with lower mean scores are: ' $\mathrm{XYZ}$ ' application can help me in finding resources related to my study' (Mean $1.53 \pm$ SD 0.790) and 'XYZ' application can help me to manage my study' (Mean $1.58 \pm$ SD 0.820). Table 5 conveys the findings on the challenges faced by the respondents. Some of the negative responses to statements such as 'help to manage my study' and 'help to develop my learning skills' are similar to the findings of Dogoriti, Pange and Anderson (2014) who indicated in their study that only 19 percent of the students demonstrated a willingness to use the online platform, 6 percent felt that their interaction and engagement in the course were increased and only 6 percent of the students agreed that they had the chance to facilitate a more active learning.

TABLE 5. Challenges in the usage of 'XYZ' application

\begin{tabular}{|c|c|c|c|c|}
\hline Items & $\begin{array}{l}\text { Disagree } \\
\mathrm{n}(\%)\end{array}$ & $\begin{array}{c}\text { Neutral } \\
\mathrm{n}(\%)\end{array}$ & $\begin{array}{l}\text { Agree } \\
\mathrm{n}(\%)\end{array}$ & Mean \pm SD \\
\hline Downloading the 'XYZ' application is easy and fast. & $153(58.2)$ & $29(11.0)$ & $81(30.8)$ & $1.73 \pm 0.904$ \\
\hline Most of the features in 'XYZ' are similar to other applications. & $37(14.1)$ & $24(9.1)$ & $202(76.8)$ & $2.63 \pm 0.719$ \\
\hline $\begin{array}{l}\text { The games on 'XYZ' lack creativity and is commonly found in } \\
\text { other applications. }\end{array}$ & 47 (17.9) & $45(17.1)$ & $171(65.0)$ & $2.47 \pm 0.780$ \\
\hline Setting up the "XYZ"s Meeting Room is quite an easy process. & $97(36.9)$ & $43(16.3)$ & $123(46.8)$ & $2.10 \pm 0.911$ \\
\hline 'XYZ's application is compatible with all smart phones. & $103(39.2)$ & $52(19.8)$ & $108(41.1)$ & $2.02 \pm 0.897$ \\
\hline $\begin{array}{l}\text { 'XYZ's Meeting Room enables multiple responses by different } \\
\text { participants to one comment. }\end{array}$ & $91(34.6)$ & $54(20.5)$ & $118(44.9)$ & $2.10 \pm 0.887$ \\
\hline The chatroom speed of text sent and text receive is efficient. & $129(49.0)$ & $41(15.6)$ & $93(35.4)$ & $1.86 \pm 0.910$ \\
\hline $\begin{array}{l}\text { 'XYZ”s Meeting Room enables participants to keep track of } \\
\text { meeting records. }\end{array}$ & $79(30.0)$ & $46(17.5)$ & $138(52.5)$ & $2.22 \pm 0.882$ \\
\hline $\begin{array}{l}\text { "XYZ"s meeting features enable multi select feature to multi- } \\
\text { forward messages to other people. }\end{array}$ & $82(31.2)$ & $64(24.3)$ & $117(44.5)$ & $2.13 \pm 0.861$ \\
\hline $\begin{array}{l}\text { There is no indication or notification showing who is typing at } \\
\text { that moment of meeting. }\end{array}$ & $46(17.5)$ & $40(15.2)$ & $177(67.3)$ & $2.50 \pm 0.776$ \\
\hline $\begin{array}{l}\text { Messages come randomly and break the flow of comments and } \\
\text { cause confusion as to which comment the message is referring to. }\end{array}$ & $43(16.3)$ & $33(12.5)$ & $187(71.1)$ & $2.55 \pm 0.760$ \\
\hline Entering in 'XYZ"s Meeting Room is easy and convenient. & $89(33.8)$ & $45(17.1)$ & $129(49.0)$ & $2.15 \pm 0.899$ \\
\hline $\begin{array}{l}\text { Entering the Meeting Room is limited to participants who have } \\
\text { been added only. }\end{array}$ & $35(13.3)$ & $41(15.6)$ & $187(71.1)$ & $2.58 \pm 0.716$ \\
\hline $\begin{array}{l}\text { Since there is no control system limiting time of comment, } \\
\text { participants contribute randomly causing some messages to } \\
\text { be overlooked. }\end{array}$ & $43(16.3)$ & $23(8.7)$ & $197(74.9)$ & $2.59 \pm 0.756$ \\
\hline $\begin{array}{l}\text { The emojis available in the Meeting Room is in Mandarin and limits } \\
\text { its usage to those competent in the language. }\end{array}$ & $47(17.9)$ & $46(17.5)$ & $170(64.6)$ & $2.47 \pm 0.780$ \\
\hline
\end{tabular}


To identify the challenges faced by the respondents in the use of 'XYZ' application in the teaching and learning process, the researchers presented 15 statements about 'XYZ' for them to state their agreement or disagreement. The respondents agreed with all the statements except for the statement 'Downloading the 'XYZ' application is easy and fast' $(58.2 \%)$ and 'The chatroom speed of text sent and text receive is efficient' (49\%). Among the challenges that the majority of respondents had agreed with are; 'Most of the features in 'XYZ' are similar to other applications' (76.8\%), 'Since there is no control system limiting time of comment, participants contribute randomly causing some messages to be overlooked' (74.9\%), 'Entering the Meeting Room is limited to participants who have been added only' (71.1\%) and 'Messages come randomly and break the flow of comments and cause confusion as to which comment the message is referring to' (71.1\%). Some of the other challenges that the respondents agreed with are that the games in 'XYZ' lack creativity and are common to those in other applications, setting up a Meeting Room is easy and it enable them to keep track of meeting records. The response to the statement 'XYZ's application is compatible with all smart phones' $(41.1 \%)$ contradicted the responses given in the other sections of the survey. Thus, the researchers sought clarification from some of the respondents informally and it was found that these respondents were using android phones. From the descriptive results with regards to challenges in the usage of ' $\mathrm{XYZ}$ ' application, the items rated as serious challenges are: 'Most of the features in 'XYZ' are similar to other applications' (Mean $2.63 \pm$ SD 0.719); 'Since there is no control system limiting time of comment, participants contribute randomly causing some messages to be overlooked' (Mean 2.59 \pm SD 0.756) and 'Entering the Meeting Room is limited to participants who have been added only' (Mean $2.58 \pm$ SD 0.716). Figure 3 shows the respondents' perceptions on the skills developed during the teaching and learning process using 'XYZ.'

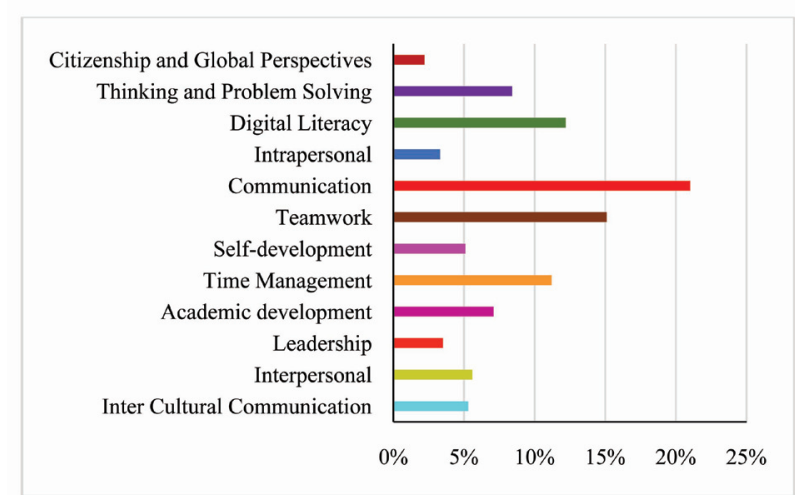

FIGURE 3. Skills developed during teaching/learning using 'XYZ'

For this question, the respondents were asked to select 3 skills which they considered were enhanced the most from the list of 12 skills given. A total of 926 responses were tabulated. The analysis of the findings in Figure 3 shows the skills that were perceived to have been enhanced the most are communication followed by team work and digital literacy. On the other hand, the skills perceived to have been least enhanced are citizenship and global perspectives, intrapersonal as well as leadership. Figures 4 and 5 show the findings from the respondents on the biggest benefit and drawback experienced during the teaching and learning process using 'XYZ' application.

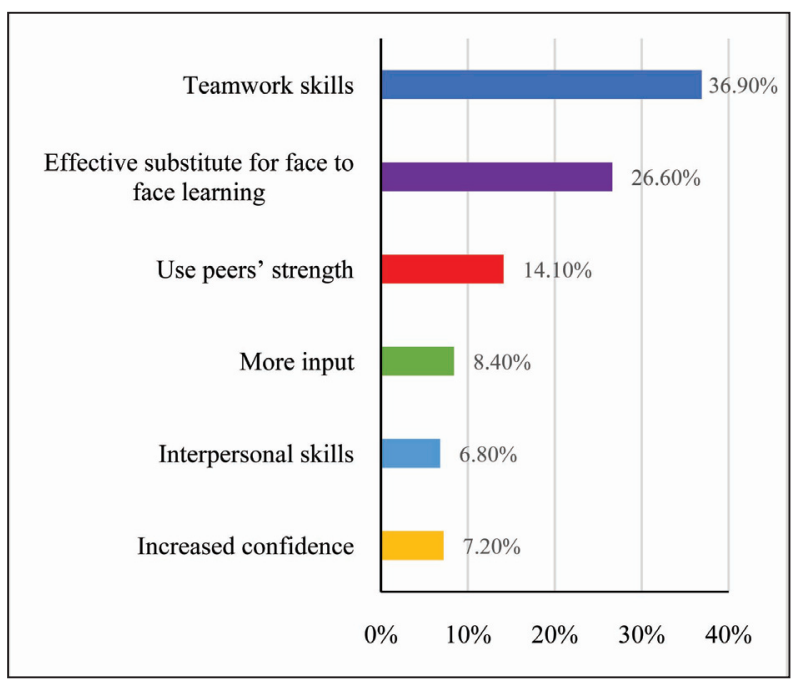

FIGURE 4. Biggest benefit of using 'XYZ' as a tool for teaching and learning

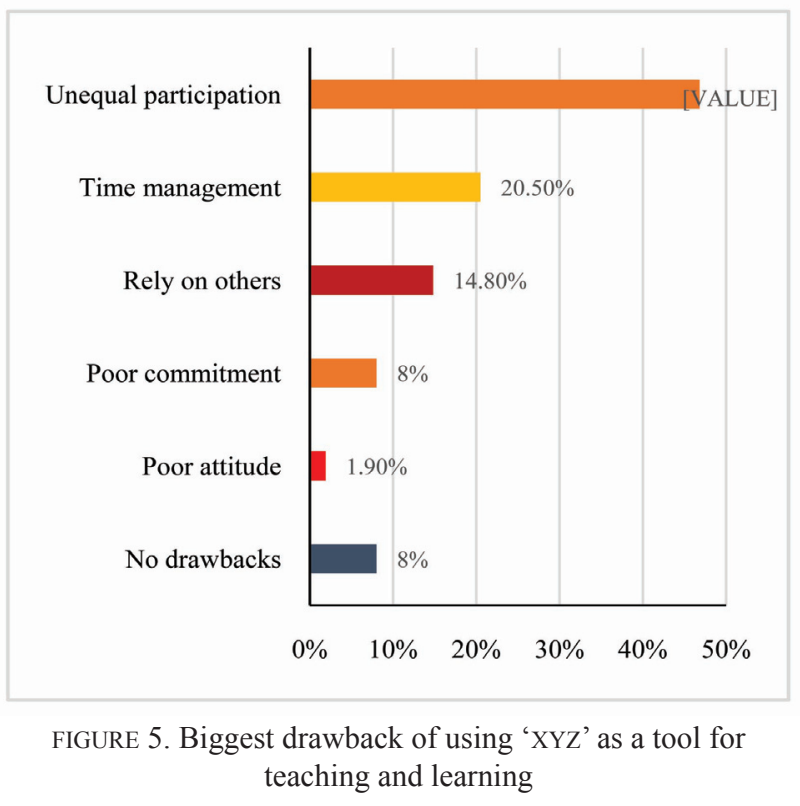

In the last part of the quantitative study, the respondents were asked to choose the biggest benefit and drawback in the use of 'XYZ' as a tool for teaching and learning from a list of 6 options as indicated in Figures 4 and 5 . The findings indicated that the biggest benefit identified by the respondents is 'Teamwork skills' while for the greatest drawback is 'Unequal participation.'

The next part of the paper discusses the findings from the interviews conducted among randomly selected students from the samples who took part in the survey. Figure 6 shows the word cloud generated by NVivo highlighting the key words used by the interviewees. 


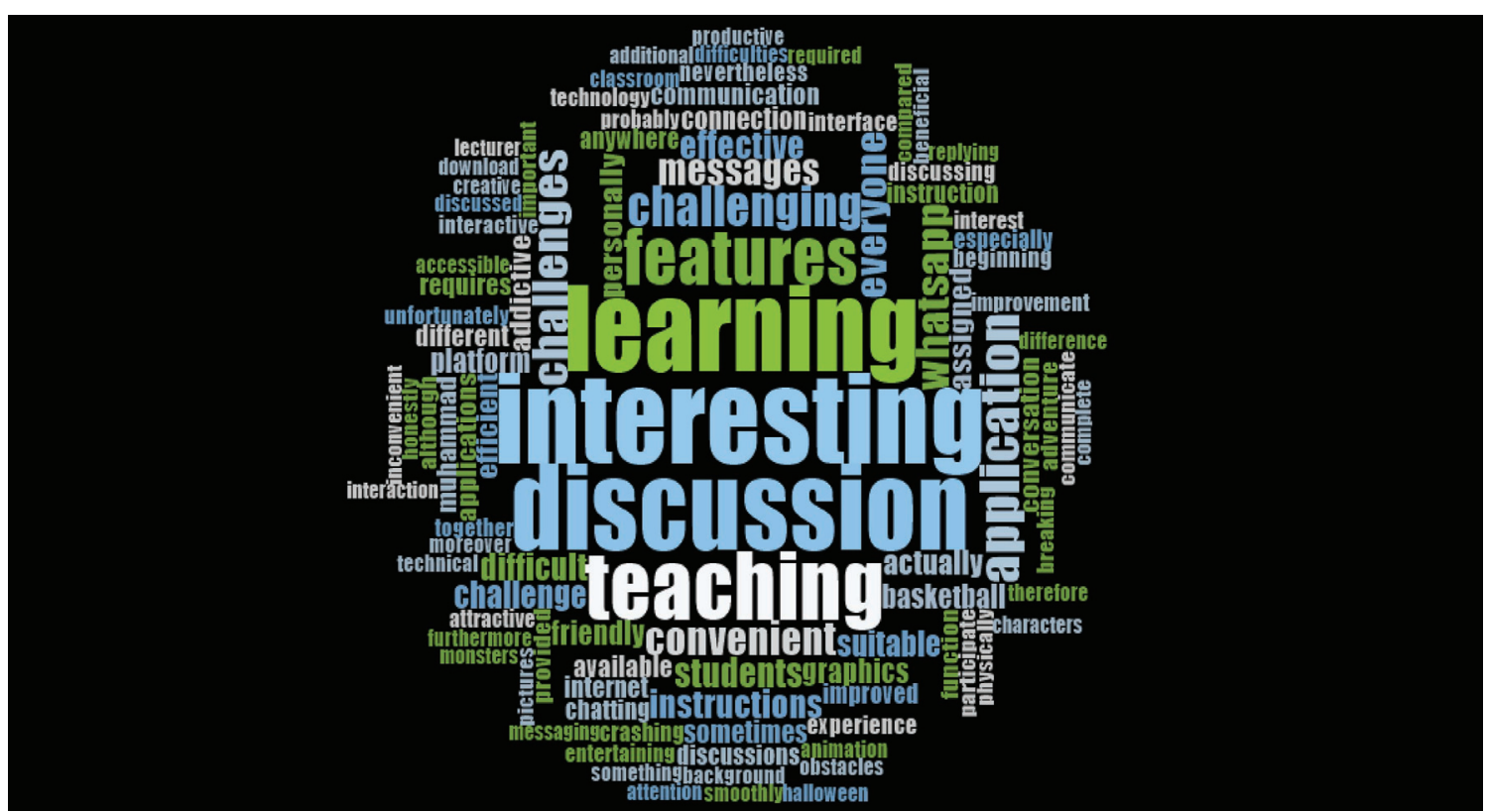

FIGURE 6. Word cloud of the whole project

The common words used by the interviewees in their responses included 'interesting,' 'convenient,' 'interaction,' 'communication,' 'discussion,' features,' 'teaching,' 'obstacles' and etc. Figure 7 shows the percentage of students' perceptions about the use of Meeting Room of 'XYZ' as a tool for teaching and learning. The responses were categorized into 2 ; positive and negative perceptions.

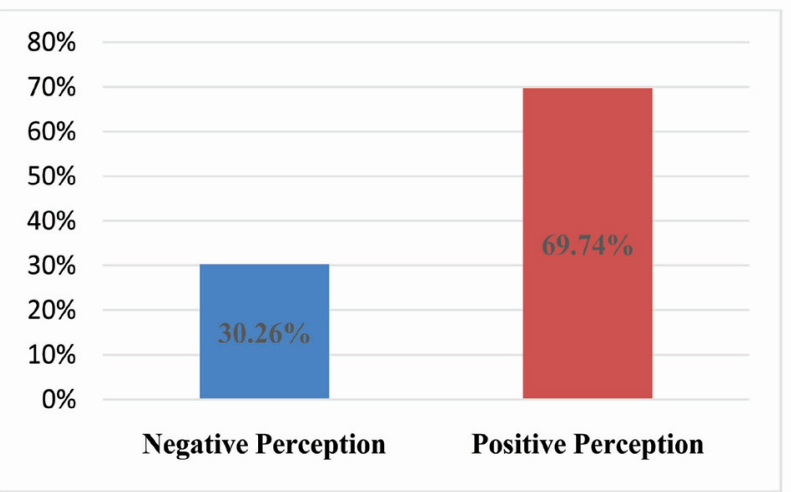

FIGURE 7. Students' perceptions about 'XYZ”'s meeting room

The analysis indicated the majority of the interviewees had positive perceptions about the use of 'XYZ"s Meeting Room as a tool for teaching and learning. A total of $69.7 \%$ viewed it positively. Some of the positive feedback given by the interviewees were; it was interesting, useful for discussion, convenient and practical, is a good platform when it is impossible or hard to be physically present together simultaneously, using Meeting Room was fun, a time-saving tool and it is interesting as we can discuss in a well-organized manner. One interviewee had a very comprehensive and positive view:

To be honest at first, I did not really think that the Meeting Room can actually be beneficial for learning process. What I thought was all about chatting random things. My perception has been changed since my tutor, course mates and I started to use it. We discuss even in an easy way and the discussion turns out to be super smooth.

This response captured most of the interviewees' initial reservations towards the use of 'XYZ' as a tool for teaching and learning. Another interviewee in her/his response compared 'XYZ' with SPECTRUM (online learning tool used in the university where the research was carried out) succinctly:

It is better than SPECTRUM's chat room as it enables us to send voice messages and attach media files too.

The interviewees also responded by highlighting some of the benefits of "XYZ"s Meeting Room. Table 6 shows the list of benefits indicated by the interviewees.

Some of the negative comments made by the interviewees were that the features of the Meeting Room are similar to other available chat rooms and "XYZ"s Meeting Room is unsuitable as a teaching tool unlike WhatsApp because it cannot send documents or reply to a person specifically. The interviewees also highlighted some challenges that they faced while using the Meeting Room. Table 7 shows the list of challenges commonly identified by the interviewees.

In addition to giving responses on the benefits of and challenges in the use of 'XYZ' as a tool for teaching and learning, the interviewees also gave some suggestions on how to improve the competitiveness of ' $\mathrm{XYZ}$ ' with other communication applications to ensure sustainability. Most of the suggestions were for designers to review "XYZ"s compatibility with the different smart phones used today. Other suggestions given were to include a reply feature so that it will be more helpful for members to address or reply to a certain discussion directly, to add an online feature to indicate those present in the meeting, to include video chat so that discussions can become efficient and productive, to 
TABLE 6. Students' perceptions on the benefits of the use of 'XYZ' as a teaching and learning tool

\begin{tabular}{ll}
\hline \multicolumn{1}{c}{ Themes } & \multicolumn{1}{c}{ Benefits } \\
\hline Time management & Can have discussion online instead of travelling to meet in faculty. \\
- Students and lecturers can communicate and hold discussion any time anywhere. & 'XYZ's application has a time limit where we can set the time for our discussion which helps a lot in \\
managing time wisely to avoid the members of the group from discussing things that are out of topic. \\
- It is equipped with good features such as emoji icons and illustrations that can help express thoughts \\
more realistically. \\
- There is opportunity to review the topic and issue that has been discussed. \\
- It has a record of all our discussion which is convenient for review at a later period. \\
- It is efficient because it has some advance features which cannot be found in other applications such \\
- In Whiteboard. \\
- The Meeting Room secures our privacy since only invited participants can join. This means that \\
our discussion is private and confidential. Besides, all chats will be deleted after the end of \\
the conversation. \\
- The interface is user friendly and nothing intrusive happened when using the application. \\
- Unlike other applications, students can be monitored by the lecturer during the discussion hence \\
- It allows people to attend meetings from wherever they are even if they are overseas. \\
- It creates a better platform for students to share their opinion especially for those who are shy and \\
Meeting Room cuts down on time required for briefing because it does not take long to start and wrap \\
up a learning session.
\end{tabular}

TABLE 7. Students' perceptions of the challenges in the use of 'XYZ' as a tool for teaching and learning

\begin{tabular}{ll}
\hline \multicolumn{1}{c}{ Themes } \\
\hline Compatibility \\
- It is not compatible with all smart phones (e.g. iPhone and IOS) \\
- Setting up of the Meeting Room is troublesome. \\
- It is tedious as the moderator had to manually add each member of the group into contacts and \\
- The Applications is quite slow. \\
- The messages slowly pop up in twos or threes. We cannot see the messages loading one by one. \\
- Messages get deleted after some time in the chat making it difficult to re-read and trace previous ideas \\
- to take note and jot down. \\
- There is a delay in receiving texts from others. \\
- It is inconvenient to apply for entrance into the Meeting Room. \\
- It is inconvenient because only ID is added and not phone number. \\
- The delay in time taken for members messages to pop up resulted in the discussion to be a bit off track. \\
- The Application is still underdeveloped where some of the instructions are in Mandarin. \\
- It does not have notifications coming in. \\
- It doesn't have the multi select feature to multi-forward messages to other people. \\
- There is no indication informing who is typing at the moment. \\
- The Meeting Room doesn't have function that we can reply to certain question as everyone \\
Features \\
- Is discussing. \\
\\
anguage \\
and learning.
\end{tabular}


include additional option of saving or highlighting some important points and to add typing notification to make discussion more effective as it is hard to keep up with who is typing and replying to which message.

The second question put forward to the interviewees was on the games found in 'XYZ.' The interviewees were requested to state their perceptions on the games and to elaborate on the interesting features of the games as well as the challenges faced while playing them. Among some of the games available in the 'XYZ' application are 'XYZ' Candy, Basketball, Brick Breaking, Halloween, Mini Racer, Dungeon Escape, Monster Run, Tora Boy Adventure, Tower Defense, Flip Coin Memory, Block Match and Box Tower. A majority of the students had positive perceptions but a small number gave negative perceptions. Those who had positive perceptions asserted that the games are interesting and the reasons given were they were full of fun, addictive, challenging and also enhanced critical thinking. On the other hand, the small number who had negative views claimed that the games were boring, simple and too common. However, on further query, it was confirmed that these negative comments were specifically related to the games Block Match, Basketball, Flip Coin Memory and Dungeon Escape. The comments on the other games were highly positive.

For the responses as to the features of the games, the interviewees responded that the colorful graphics, clear video and background music were excellent, interesting and catchy. They also said that the animation and interfaces were very attractive. There were hardly any negative comments about the features of the games. Despite the positive comments about most of the games and their features, the interviewees highlighted a number of challenges that they had faced. Among these were that some of the games took a long time to load, the games crashed at critical moments causing them to lose marks accumulated and crucial instructions were missing (e.g. Dungeon Escape and Tora Boy Adventure) or vague instructions (e.g. 'XYZ' Candy and Tower Defense). It must be noted here that the interviewees raised a serious concern similar to those of the survey respondents which is that 'XYZ"s features are only suitable for android mobile phones and that users of other phones such as iPhone had a lot of issues in terms of downloading and using the application.

The findings of the study from the survey and interviews provided clear outcomes to the research objectives. The descriptive results of the items indicated in Table 3 clearly show only 4 items of 'XYZ' are better than the other communication applications compared to in the study. With regards to students' perceptions on the use of 'XYZ' as a tool for teaching and learning, a majority of the interviewees had positive perceptions about the use of the Meeting Room of 'XYZ'. The interviewees also gave positive comments on the features of the games found in 'XYZ.' Among the benefits highlighted were it is time saving, efficient and has attractive features. In terms of challenges, the interviewees highlighted that the tool is not compatible with some smart phones and the use of Mandarin as the language of instruction for some of the features caused difficulty for non-Mandarin speakers.

\section{MANAGERIAL IMPLICATION}

This study has some implications for both management and academics. The management of higher learning institutions need to be alert of the strengths and shortcoming in the 'XYZ' application as a tool for teaching and learning by ensuring only the positive features of the application are used by their academic staff. For instance, among some of the key findings under the challenges perceived by the students are issues related to compatibility, efficiency, use of language and the features of the application. As such, the academicians must ensure that their students have mobiles that are compatible with the application to ensure there are no hiccups in the process of using the application. Further, note must be taken that the application is still not efficient as some of its features are not stable and crash at crucial times. Caution must also be taken in the use of the application due to the use of Mandarin which is not an international language and students might not be able to comprehend the instructions. Thus, it can be said that the application has some weaknesses which limit its effectiveness as a tool for teaching and learning and as such these must be borne in mind by the academicians when deciding to use this application. Furthermore, since this study has an element of comparison, the management of these institutions should encourage their academic staff to adopt applications that best suit the objectives of the tasks set in their teaching and learning process. The management should also caution their staff to be alert of the shortcomings of the features of the different communication applications so as to ensure that the teaching and learning process is not impeded by these shortcomings.

\section{CONCLUSION}

According to a recent research, "the coming into being of SNSs have revolutionized the world of communication and today we celebrate its improvements ranging from education to entertainment" (Kolan \& Dzandza 2018). This is evident in the way M-learning technologies have transformed the teaching and learning processes in institutions of higher learning. Currently, there are numerous SNSs that are being incorporated in the field of education such as Facebook, WhatsApp, WeChat, Line and Snapchat etc. The current study was carried out to identify the perceptions of undergraduate law students on the use of 'XYZ' application as a tool for teaching and learning in higher education institutions. The findings indicate that students perceived 'XYZ"'s Meeting Room as an effective tool for conducting discussion when it was not possible to meet face to face specifically during public holidays 
and semester breaks. However, strong criticism was made about the application's incompatibility with smart phones other than androids. Moreover, the interviewees stated that some of the games have unclear instructions or do not have instructions at all, causing difficulties for them to enjoy the games. The use of Mandarin for certain instructions also created difficulties for non-Mandarin speakers.

Based on the findings, the researchers recommend that designers of ' $\mathrm{XYZ}$ ' application should focus on alleviating the weaknesses to ensure that this application is on par with other SNSs available. This will in the long run ensure popularity among users and sustainability of the application. In addition, since the current study focused only on undergraduate students' perceptions of the Meeting Room feature and the games available in ' $\mathrm{XYZ}$ ' application, the authors recommend that future studies should be carried out with focus on other features of 'XYZ' and to include a larger and more diversified sample to obtain a more comprehensive, valid and reliable view of the application.

\section{REFERENCES}

Al Emran, M. \& Shaalan, K. 2014. E-podium technology: A medium of managing knowledge at Al Buraimi University College via M-learning. In $2^{\text {nd }} \mathrm{BCS}$ international IT conference 10 March, Abu Dhabi, UAE.

Alshahrani, K. \& Al-Shehri, S. 2012. Conceptions and responses to e-learning: The case of EFL teachers and students in a Saudi Arabian university. Monash University Linguistics Papers 8(1): 21-31.

Baran, B. 2010. Facebook as a formal instructional environment. British Journal of Educational Technology 41(6): 146149.

Bouhnik, D. \& Deshen, M. 2014. WhatsApp goes to school: Mobile instant messaging between teachers and students Journal of Information Technology Education: Research 13(1): 217-231

Boyd, D.M. \& Ellison, N.B. 2007. Social network sites: Definition, history and scholarship, Journal of Computermediated Communication 13(1): 210-230.

Cheon, J., Lee, S., Crooks, S.M. \& Song, J. 2012. An investigation of mobile learning readiness in higher education based on the theory of planned behavior. Computers \& Education 59(3): 1054-1064.

Churchill, D. 2009. Educational applications of Web 2.0: Using blogs to support teaching and learning. British Journal of Educational Technology 40(1): 179-183

Cox, J.T. \& Rethman, K.M. 2011. Personal use of social networking by employees-both on the job and off the clockcan cause major headaches for employers who fail to take the proper precautions. Ohio Lawyer.

Darwish, A. \& Lakhtaria, K.I. 2011. The impact of the new Web 2.0 technologies in communication, development, and revolutions of societies. Journal of Advances in Information Technology 2(4): 204-216.

de Villiers, M.R. 2010. Academic use of a group on Facebook - initial findings and perceptions. Informing Science and IT Education Conference. Gauteng: University of South Africa.
Dogoriti, E., Pange, J. \& S. Anderson, G. 2014. The use of social networking and learning management systems in English language teaching in higher education. Campus-Wide Information Systems 31(4): 254-263.

Edosomwan, S., Prakasan, S.K., Kouame, D., Watson, J. \& Seymour, T. 2011. The history of social media and its impact on business. Journal of Applied Management and Entrepreneurship 16(3): 79-91.

Gasmi, A. 2014. Mobile assisted language learning: Potential and limitations of using 'Whatsapp'Messenger to enhance students writing skills. In INTED2014 Proceedings. 72437243. IATED.

Girgin, U., Kurt, A. \& Odabasi, F. 2011. Technology integration issues in a special education school in Turkey. Cypriot Journal of Educational Sciences 6(1): 13-21.

Greenhow, C. 2011. Online social networking and learning: What are the interesting research questions? International Journal of Cyber Behavior, Psychology and Learning (IJCBPL) 1(1): 36-50.

Hahn, J. 2008. Mobile learning for the twenty-first century librarian. Reference Services Review 36(3): 272-288

Iqbal, S. \& Qureshi, I.A. 2012. M-learning adoption: A perspective from a developing country. The International Review of Research in Open and Distributed Learning 13(3): 147-164.

Junco, R., Heiberger, G. \& Loken, E. 2011. The effect of Twitter on college student engagement and grades. Journal of Computer Assisted Learning 27(2): 119-132.

Kabilan, M.K.,Ahmad, N. \& Abidin, M.J.Z. 2010. Facebook: An online environment for learning of English in institutions of higher education? The Internet and Higher Education 13(4): 179-187.

Keenan, A. \& Shiri, A. 2009. Sociability and social interaction on social networking websites. Library Review 58(6): 438-450.

Kietzmann, J.H., Hermkens, K., McCarthy, I.P. \& Silvestre, B.S. 2011. Social media? Get serious! Understanding the functional building blocks of social media. Business Horizons 54(3): 241-251.

Kolan, B.J. \& Dzandza, P.E. 2018. Effect of social media on academic performance of students in Ghanaian Universities: A case study of University of Ghana, Legon. Library Philosophy and Practice 1-24.

Kuppuswamy, S. \& Narayan, P. 2010. The impact of social networking websites on the education of youth. International Journal of Virtual Communities and Social Networking 2(1): 67-79.

Lynch, M. 2017. 7 Ways that digital technology is changing the face of education. Available at http://www.thetechedvocate. org/7-ways-digital-technology-changing-face-education/.

Mahdi, H.S. \& El-Naim, M.E.M. 2012. The effects of informal use of computer-mediated communication on EFL learner interaction. Studies in Literature and Language 5(3): 7581

Mangold, W.G. \& Faulds, D.J. 2009. Social media: The new hybrid element of the promotion mix. Business Horizons 52(4): 357-365.

Mason, R. 2006. Learning technologies for adult continuing education. Studies in Continuing Education 28(2): 12133.

Mayur, D. \& Ojode, L. 2017. Implications of social media use on instruction and student learning: An exploratory study. Southwestern Business Administration Journal 16(1): $1-11$. 
Mazer, J.P., Murphy, R.E. \& Simonds, C.J. 2007. I'll see you on "Facebook": The effects of computer-mediated teacher self-disclosure on student motivation, affective learning, and classroom climate. Communication Education 56(1): $1-17$.

Mcconatha, D., Praul, M. \& Lynch, M.J. 2008. Mobile learning in higher education: An empirical assessment of a new educational tool. The Turkish Online Journal of Educational Technology 7(3): 15-21.

Mirski, P.J. \& Abfalter, D. 2004. Knowledge enhancement on site-guests' attitudes towards m-learning. In Proceeding of the Information and Communication Technologies in Tourism 2004, 11th ENTER international conference in Cairo, (ICC'04), Cairo, Egypt, 592-600.

Ngaleka, A. \& Uys, W. 2013. M-learning with WhatsApp: A conversation analysis. In International Conference on e-Learning, 282. Academic Conferences International Limited.

Nicholson, S. 2011. Infographics: The history of online social networking, Available at http://socialmediatoday.com/ socmedsean/286629/infographic-history-online-socialnetworking, April 17

The Nielsen Company. 2010. What Americans do online social media and games dominate activity. Available at http://blog. nielsen.com/nielsenwire/online_mobile/whatamericans-doonline-social-media-and-games-dominate-activity/

Ofcom. 2017. Children and parents: Media use and attitudes report. Available at https://www.ofcom.org.uk/_data/ assets/pdf_file/0020/108182/children-parents-media-useattitudes-2017.pdf

Rau, P.L.P., Gao, Q. \& Wu, L.M. 2008. Using mobile communication technology in high school education: Motivation, pressure, and learning performance. Computers \& Education 50(1): 1-22.

Roblyer, M.D., McDaniel, M., Webb, M., Herman, J. \& Witty, J.V. 2010. Findings on Facebook in higher education: A comparison of college faculty and student uses and perceptions of social networking sites. The Internet and Higher Education 13(3): 134-140.

Selwyn, N. 2009. Faceworking: Exploring students' educationrelated use of Facebook. Learning, Media and Technology 34(2): 157-174.

Sharples, M., Taylor, J.É. \& Vavoula, G. 2005. Towards a theory of mobile learning. In Proceedings of mLearn 1(1): 1-9.
Smith, B.G. 2010. Socially distributing public relations: Twitter, Haiti, and interactivity in social media. Public Relations Review 36(4): 329-335.

Wang, M. \& Shen, R. 2012. Message design for mobile learning: Learning theories, human cognition and design principles. British Journal of Educational Technology 43(4): 561575.

Yalcinalp, S. \& Gulbahar, Y. 2010. Ontology and taxonomy design and development for personalised web-based learning systems. British Journal of Educational Technology 41(6): 883-896.

Saroja Dhanapal (corresponding author)

Faculty of Law

University of Malaya

50603 Kuala Lumpur, MALAYSIA.

E-Mail: saroja.dhanapal@um.edu.my

Nadhratul Wardah Salman

Faculty of Law

University of Malaya

50603 Kuala Lumpur, MALAYSIA.

E-Mail: wardah@um.edu.my

Gopinathan K. Raman Kutty

Faculty of Education

University of Malaya

50603 Kuala Lumpur, MALAYSIA.

E-Mail: gopi@fairview.edu.my

Khalid M.S. Ansari

Faculty of Law

University of Malaya

50603 Kuala Lumpur, MALAYSIA.

E-Mail: ansari@siswa.um.edu.my

Sardar Ali Shah

Faculty of Law

University of Malaya

50603 Kuala Lumpur, MALAYSIA.

E-Mail: sardarshah@siswa.um.edu.my 